\title{
Sosyal Medya Kullanımının Kadınların Estetik Cerrahiye İlişkin Tutumlarına Etkisi
}

\author{
The Effect of Social Media Use on Women's Attitudes Towards Aesthetic Surgery
}

İzmir Bakırçay Üniversitesi Sağlık Bilimleri Fakültesi Hemşirelik Bölümü, İzmir, Türkiye

Correspondence:

Aliye OKGÜN ALCAN

İzmir Bakırçay Üniversitesi Sağlık

Bilimleri Fakültesi Hemşirelik

Bölümü, İzmir, Türkiye

e-mail: aliyeokgun@gmail.com
Aliye Okgün Alcan, Serpil Çetin

\section{Özet}

Estetik cerrahi geçirme isteği tüm dünyada olduğu gibi ülkemizde de giderek artmaktadır. Bu çalışmanın amacı sosyal medya kullanımının kadınların estetik cerrahiye ilișkin tutumlarına etkisinin belirlenmesidir. Bu çalıșma, tanımlayıcı tipte, kesitsel desende olup, Aralık 2020 - Mart 2021 tarihleri arasında çevrim içi ortamda gerçekleștirilmiștir. Çalıșmanın örneklemini araștırmaya katılmayı gönüllü olarak kabul eden, aktif olarak internet kullanan, 18 yaş ve üzeri 315 kadın oluşturmuştur. Bu çalışmada katılımcılar deney (n:157) ve kontrol (n:158) grubu olmak üzere iki gruba ayrılmıştır. Çalışmanın verileri sosyodemografik özellikler formu ve Kozmetik Cerrahi Kabul Ölçeği (KCKÖ) kullanılarak toplanmıștır. Kontrol grubunda yer alan katılımcıların veri toplama formunda manzara temalı resimler; deney grubunda yer alan katılımcıların veri toplama formunda ise estetik cerrahi geçirmiş kadın temalı resimler kullanılmıştır. Verilerin değerlendirilmesinde tanımlayıcı istatistikler, Mann Whitney U ve Kruskal Wallis testi kullanılmıştır. Araştırmanın yürütülebilmesi için bir üniversitenin girişimsel olmayan klinik araştırmalar etik kurulundan yazılı izin alınmıștır. Calıșmaya dahil edilen kadınların yaș ortalaması $31.3 \pm 11.5$ ve beden kitle indeksi ortalaması $23.2 \pm 4.0 \mathrm{~kg} / \mathrm{m} 2$ olarak belirlenmiștir. Kadınların \%63.5’i estetik amaçlı bir ameliyat geçirmeyi istediğini belirtmiştir. Kontrol grubunun KCKÖ toplam puan ortalamasının $46.4- \pm 20.8$; deney grubunun ise $54.8 \pm 23.3$ puan olduğu belirlenmiştir. Deney grubuna alınan kadınların KCKÖ toplam puan ortalamasının kontrol grubuna alınan kadınların puan ortalamasından istatistiksel olarak anlamlı düzeyde yüksek olduğu saptanmıștır (p:0.002). Bu çalıșma sonucunda estetik cerrahi geçiren kadın resimlerinin sosyal medya aracılığıyla takip edilmesinin kadınların beden imajı üzerinde olumsuz etkisi olduğu dolayısıyla estetik cerrahi geçirmeye yönelimi arttırdığı belirlenmiştir.

Anahtar Kelimeler: Estetik cerrahi tutumu; sosyal medya kullanımı; kadın

\section{Abstract}

The desire to undergo aesthetic surgery is increasing in our country as well as all over the world. The aim of this study is to determine the effect of social media use on women's attitudes towards aesthetic surgery. This study is a descriptive, cross-sectional design, and was conducted online between December 2020 and March 2021. The sample of the study consisted of 315 women aged 18 and over, who voluntarily accepted to participate in the study and actively used the internet. Participants in this study were divided into two groups as experimental (n: 157) and control (n: 158) groups. The data of the study were collected using the sociodemographic characteristics and the Cosmetic Surgery Acceptance Scale (CSAS). Landscape themed pictures in the data collection form of the participants in the control group; In the data collection form of the participants in the experimental group, pictures with the theme of women who had undergone aesthetic surgery were used. Descriptive statistics, Mann Whitney U and Kruskal Wallis tests were used to evaluate the data. Written permission was obtained from the non-interventional clinical research ethics committee of a university to conduct the study. The average age of the women included in the study was $31.3 \pm 11.5$ and the mean body mass index was $23.2 \pm 4.0 \mathrm{~kg} / \mathrm{m} 2.63 .5 \%$ of the women stated that they wanted to undergo an aesthetic surgery. The mean CSAS total score of the control group was $46.4 \pm 20.8$; the experimental group was determined to be $54.8 \pm 23.3$. It was determined that the mean CSAS total score of the women in the experimental group was statistically significantly higher than the average score of the women included in the control group (p:0.002). As a result of this study, it was determined that following the pictures of women who have undergone aesthetic surgery through social media has a negative effect on the body image of women, thus increasing the tendency to have aesthetic surgery.

Keywords: Aesthetic surgery attitude; use of social media; woman 


\section{Giriş}

Fiziksel görünüm, kişisel kimliğin önemli bir yönüdür ve bireylerin öz algısıyla ilişkisi yaşamın erken dönemlerinde başlar. Bireylerin güzellik algısını etkileyen üç temel sosyokültürel faktörün akranlar, ebeveynler ve medya olduğu bilinmektedir. Bu faktörlerin etkileriyle bireyler fiziksel görünüm ideallerini içselleştirilmekte ve görünümlerini farklı bireylerle karşılaştırmaktadırlar. İçselleştirme, bir kişinin toplumun güzellik ideallerini kabul etmesi ve bu ideale ulaşmak için davranışlarda bulunmasıyla ortaya çıkmaktadır. Görünüm karşılaştırması, nasıl göründüklerine bağlı olarak kendilerini başkalarıyla doğrudan karşılaştıran ve değerlendiren insanlarla ilgilidir. Bir kişinin, sahip olmadığı fiziksel görünüm hakkındaki güzellik ideallerini içselleştirmesi ve görünüş karşılaştırmasına girmesinin beden imajıyla ilgili sorunlar yaratabileceği öne sürülmektedir. Bunun sonucunda fiziksel görünümlerinden memnun olmayan kişilerin estetik cerrahiye başvurma oranları giderek artmaktadır (1-3). Uluslararası Estetik Plastik Cerrahi Derneği'nin (International Society of Aesthetic Plastic Surgery) verilerine göre 2019 y1lında Dünya'da 11.363.569 cerrahi ve 13.618.735 cerrahi olmayan estetik amaçl1 işlem gerçekleştirilmiş olup ülkemizde 351.930 cerrahi ve 402.462 cerrahi olmayan olmak üzere toplam 754.392 estetik amaçlı işlem gerçekleştirildiği belirtilmektedir (4).

Fiziksel görünümün güzel olması özellikle kadınlar için kadınsı olmanın temelini oluşturduğu için önem taşımaktadır $(5,6)$. Kendi fiziksel görünümünü ve bedenine ilişkin olumsuz düşüncelere sahip olan kişilerin bu durumla baş edebilmek ve yaşam kalitelerini arttırmak için başvurduğu yöntemlerden bir tanesi estetik cerrahidir (57).

Televizyon programları, reklamlar, dergiler gibi geleneksel medya formatlarının genç kadınların estetik cerrahiyi düşünmeleri üzerindeki etkisini inceleyen birçok araştırma bulunmaktadır. Son yıllarda sosyal medyanın artan popülaritesi göz önüne alındığında, araştırmacılar bu yeni medya formatlarının vücut imajı üzerindeki olası sonuçlarını araştırmaya başlamışlardır. Ancak, yine de kadınların estetik cerrahi, kozmetik tedavi yaptırma kararını etkileyen faktörleri belirlemeye yönelik çalışmalar oldukça sinırlidir $(3,8)$.

Medyanın, 'ideal beden'e odaklanan mesajların iletilmesi yoluyla, toplumların beden imajı, yani kişinin hangi vücut tipine sahip olması gerektiği, ne giymesi gerektiği hakkındaki fikirleri üzerinde güçlü bir etkiye sahip olduğu bilinmektedir $(3,8)$. Bununla birlikte, günümüzde giderek kullanımı artan sosyal ăg siteleri gibi daha yeni medya biçimlerinin estetik cerrahiye ilişkin tutumlarını nasıl etkilediğini inceleyen çalışma sayısı oldukça sınırlıdır $(1,3)$. Bu nedenle bu araştırma sosyal medya kullanımının kadınların estetik cerrahiye ilişkin tutumlarına etkisinin belirlenmesi amaciyla yürütülmüştür.

\section{Gereç ve Yöntemler}

Tanımlayıcı tipteki bu çalışmanın amacı sosyal medya kullanımının kadınların estetik cerrahiye ilişkin tutumlarına etkisinin belirlenmesidir. Walker ve arkadaşları (2019) tarafindan yapılan benzer çalışmadaki veriler baz alınarak yapılan G-Power 3.1 istatistiksel program ile priori (önsel) güç analizi yapılmıştır (3). Tip I hata 0.05 , testin gücü 0.80 iken çalışmada her grup için 57 olmak üzere gerekli minimum örneklem 114 kişi (\%5 hata payı ile) olarak belirlenmiştir. Bu çalışmada katılımcılar deney ve kontrol grubu olmak üzere iki gruba ayrılmıştır. Tanımlayıcı tipteki çalışmanın örneklemini araştırmaya katılmayı gönüllü olarak kabul eden, aktif olarak internet kullanan, 18 yaş ve üzeri 315 kadın (kontrol:158 deney:157) oluşturmuştur.

Araştırmanın verileri Aralık 2020 - Mart 2021 tarihleri arasında "Sosyodemografik Özellikler Formu" ve 'Estetik Cerrahi Kabul Ölçeği' kullanılarak toplanmıştır. Araştırmacılar tarafından geliştirilen veri toplama formu 3 bölümden oluşmaktadır. Sosyodemografik Özellikler Formunun birinci bölümü toplam 9 sorudan oluşan; katılımcıların yaş, cinsiyet, eğitim durumu gibi sosyo-demografik özellikleri, sosyal 
medya kullanımlarının belirlenmesine yönelik soruları içermektedir. Formun ikinci kısımda "Resim Setleri" yer almaktadır. Çalışmada kontrol ve deney gruplarında ayrı ayrı kullanılmak üzere iki ayrı resim seti kullanılmıştır. Kontrol grubunda manzara temalı 15 adet resim kullanılmıştır. $\mathrm{Bu}$ resimler araştırmacılar tarafindan internetten taranarak telif hakkı içermeyen, renkli manzara resimleri $(\sim 750 \times 750$ piksel $)$ arasından seçilmiştir. Deney grubunda kullanılan resim setinde ise estetik cerrahi geçirmiş kadın temalı resimler kullanılmıștır. $\mathrm{Bu}$ resimlerin belirlenebilmesi için çalıșmaya dahil edilme kriterlerine uyan 10 kadın ile ön çalışma yapılmıştır. Bunun için katılımcıların sosyal medyada rahatlıkla karşılaşabilecekleri, telif hakkı bulunmayan, renkli, kadınlar tarafından en çok tercih edilen estetik cerrahi işlemlerden en az birini geçirmiş, 30 tane kadın görseli seçilerek ön çalışma yapılan kadınlara gösterilmiștir. Katılımcılardan resimde yer alan kişinin estetik ameliyat geçirip geçirmediğine dair düşüncelerini, başarılı olup olmadığını, fiziksel görüşünü ve ilgili resmin sosyal medya üzerinde rahatlıkla karşılaşılabilecek nitelikte olup olmadığını 010 puan arasında değerlendirmesi istenmiştir. Değerlendireler sonucunda katılımcıların her resim için verdikleri puanlar toplanarak en yüksek puan alan 15 resim ana çalışmada kullanılmıştır. Ön çalışmaya dahil olan katılımcılar ana çalışmaya dahil edilmemiştir. Formun üçüncü kısmında ise katılımcıların estetik cerrahi ve kendi fiziksel görünüşleri hakkındaki görüşlerini içeren sorular bulunmaktadır.

$\mathrm{Bu}$ çalışmada katılımcıların estetik cerrahiye ilişkin tutumlarını belirlemek amacıyla "Kozmetik Cerrahi Kabul Ölçeği (KCKÖ)" kullanılmıştır. Henderson-King (2005) tarafından geliştirilen KCKÖ 15 maddelik bir ölçektir. Ölçeğin Türkçe geçerlik ve güvenirliği Karaca ve arkadaşları (2017) tarafından yapılmıștır. KCKÖ 7'li likert tipte (1=Hiç katılmıyorum, $\quad$ =Tamamen katılıyorum) olup hem üç alt boyuta hem de ölçek toplam puanına göre değerlendirilebilmektedir. KCKÖ'nün puan aralığ1 15-105'tir. Alt boyutlar ve ölçek toplam puanının yükselmesi estetik cerrahiye ilişkin tutumların olumlu olduğunu gösterir.
Ölçeğin alt boyutları; kişisel, sosyal ve düşüncelerdir. Kişisel alt boyutunda; kozmetik cerrahi için motivasyon sağlayan, bireylerin görünümleriyle ilgili kişisel değerlendirmeleri yer almaktadır. Sosyal; alt boyutunda bireylerin sosyal ilişkilerinde ve sosyal ortamlarda kendilerini daha iyi hissetmeleri ile ilgili estetik cerrahiyi olumlayan tutumlar belirlenmektedir. Düşünceler alt boyutunda ise bireylerin estetik cerrahi ile ilgili görüşleri değerlendirilmektedir. Henderson-King'in çalışmasında ölçeğin iç tutarlılığının yüksek (Cronbach alfa .91 ile .93 arasında) olduğu bildirilmektedir. Ölçek alt boyutlardan ve ölçeğin tamamından alınan puanlarla değerlendirilebilmektedir. Ölçeğin alt boyutlar ve toplam puanının yüksek olması kişinin estetik cerrahiyi kabul ettiğini ifade eder (9). $\mathrm{Bu}$ çalışmada ölçeğin Cronbach Alpha katsayısı 0.94 olarak hesaplanmıştır.

$\mathrm{Bu}$ çalışmada Türkiye genelinde yaşayan kadınlara ulaşabilmek için veriler internet üzerinden toplanmıştır. Çalışmanın yürütülebilmesi için gerekli izinler alındıktan sonra deney ve kontrol gruplarına ait veri toplama formları elektronik ortamda ayrı ayr1 yayımlanmıştır. Çalışmaya davet sosyal paylaşım siteleri üzerindeki gruplardan yapılmıştır. Bir katılımcının hem deney hem de kontrol grubuna dahil olmasını önlemek için her iki grup için ayrı davet mektupları oluşturularak farkl1 sosyal medya gruplarından paylaşım yapılmıștır. Ayrıca veri toplama işlemi sonrası deney ve kontrol gruplarına ait katılımcıların IP denetlemesi sağlanmıştır.

Araştırmanın yürütülebilmesi için bir üniversitenin girişimsel olmayan klinik araștırmalar etik kurulundan yazılı izin alınmıştır (Tarih:25.12.2020 Karar no:140). $\mathrm{Bu}$ çalışmada katılımcıların çalışmanın amacını bilmesi çalışma verilerini etkileyebilecektir. Bu nedenle çalışmaya davet edilirken çalışmanın amacı sosyal medyada kullanılan görsellerin incelenmesi olarak açıklanmıştır. $\mathrm{Bu}$ bilgiye veri toplama formunun başında yer verilmiştir. Katılımcılar veri toplama formunda yer alan soruları cevapladıktan sonra çalışmanın asıl amacı katılımcılara açıklanmıştır. $\mathrm{Bu}$ bilgiler 
doğrultusunda veri toplama formunun altında "Çalışmaya katılmayı kabul ediyorum, cevapladığım soruları kaydet" ve "Çalışmaya katılmayı kabul etmiyorum, çalışmadan geri çekil" seçenekleri yer almıştır. Bu doğrultuda çalışmaya katılmayı kabul eden katılımcıların veri toplama formları kayıt altına alınmıștır. Çalışmada kullanılan "Kozmetik Cerrahi Kabul Ölçeği" için ölçeğin Türkçe geçerlik ve güvenirlik çalışmasını yapan araştırmacılardan biri olan Ayşe Karakoç'tan elektronik posta aracılığıyla izin alınmıştır.

\section{İstatistiksel analiz}

Araştırmadan elde edilen veriler Statistical Package for the Social Sciences for Windows 20.0 paket programı kullanılarak analiz edilmiştir. Verilerin değerlendirilmesinde tanımlayıcı istatistikler (sayı, yüzde, ortalama, standart sapma) kullanılmıştır. Verilerin normal dağılım gösterip göstermediğini belirlemek için Kolmogorov Smirnov Testi kullanılmıştır. Deney ve kontrol gruplarının KCKÖ puan ortalamalarının analizinde MannWhitney $U$ ve Kruskal Wallis testi uygulanmıştır. Tüm sonuçlarda $p$ değeri 0.05 'den küçük değerler istatistiksel olarak anlamlı kabul edilmiştir $(\mathrm{p}<0.05)$.

\section{Bulgular}

$\mathrm{Bu}$ çalışmada katılımcıların yaş ortalamasının $31.3 \pm 11.5$ (min: 18 maks:69) y1l; beden kitle indeksi ortalamasının $23.2 \pm 4.0 \mathrm{~kg} / \mathrm{m} 2$ olduğu belirlenmiştir. Araştırma kapsamına alınan kadınların \%92.1'inin sosyal medyayı aktif olarak kullandıkları saptanmıştır. Araştırma kapsamına alınan bütün kadınların sosyodemografik ve sosyal medya kullanım özelliklerine göre dağılımı tabloda verilmiştir (Tablo 1).

Tablo 1. Katılımcıların sosyo-demografik ve sosyal medya kullanım özelliklerine göre dağılımları

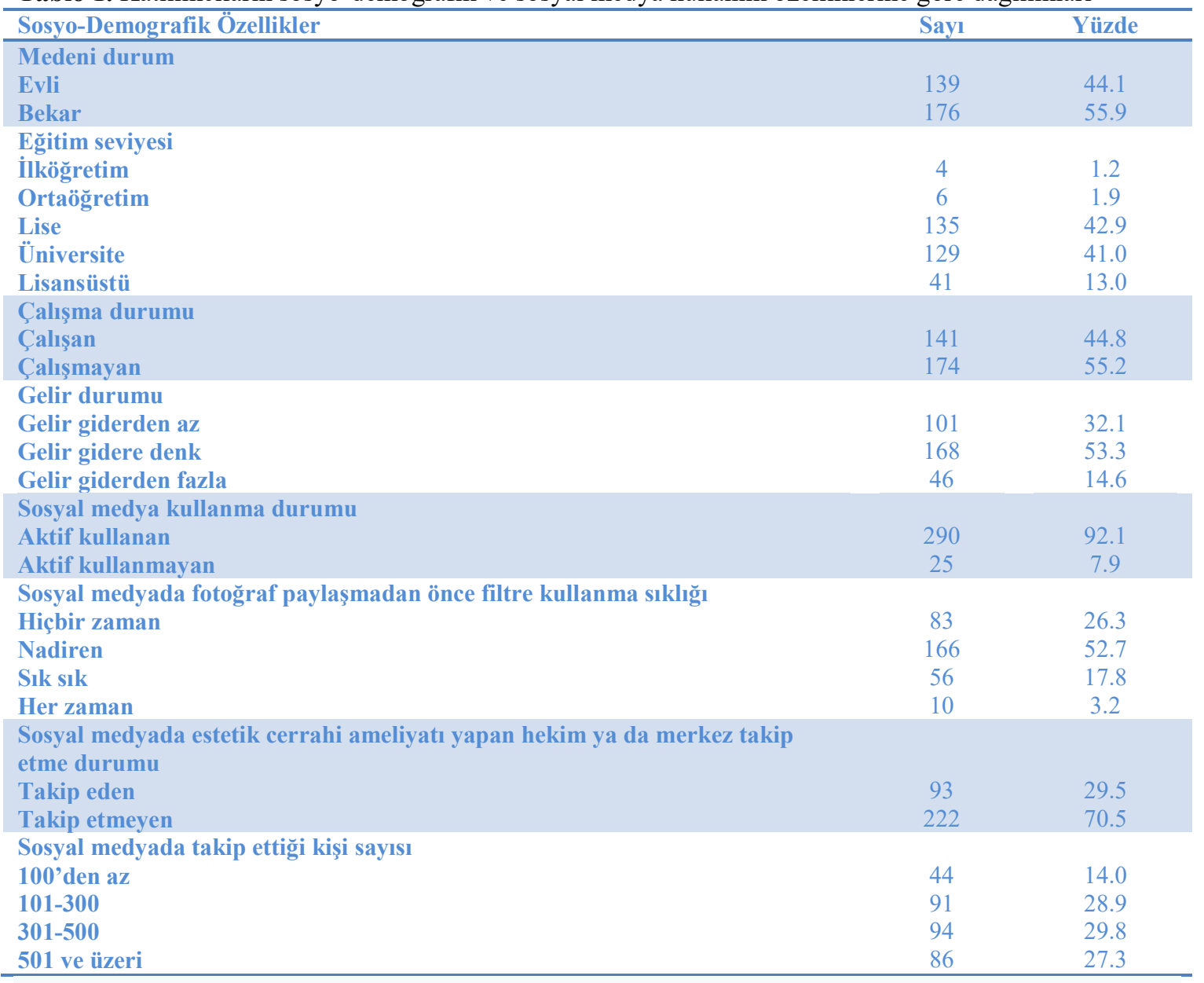


Kadınların kendi görünüşlerinden memnuniyet düzeyi puan ortalamalarının 10 üzerinden $7.0 \pm 1.9$ (min:0 maks:10) olduğu görülmüştür. $\mathrm{Bu}$ çalışmada kadınların \%89.8'inin daha önce estetik amaçlı herhangi bir ameliyat ya da işlem geçirmediği saptanmıştır. Kadınların \%57.8'inin yakın çevresinden bir kişinin daha önce estetik amaçlı bir ameliyat geçirdiği belirlenmiştir.
Çalışmaya dahil edilen kadınların \%63.5'i vücudunun herhangi bir yerini beğenmediği için estetik amaçlı bir ameliyat geçirmeyi istediğini belirtmiştir. Kadınların estetik amaçlı ameliyat geçirmek istedikleri bölgelerinin s1klıkla burun (\%33.7), meme $(\% 21.0)$ ve karın (\%8.9) olduğu saptanmıştır (Tablo 2).

Tablo 2. Katılımcıların estetik cerrahiye ilişkin deneyimlerine göre dağılımları

\begin{tabular}{lcc}
\hline Değişken & Sayı & Yüzde \\
\hline Daha önce estetik amaçlı herhangi bir ameliyat ya da işlem geçirme durumu & 32 & 10.2 \\
Geçiren & 283 & 89.8 \\
Geçirmeyen & & \\
Yakın çevresinden bir kişinin daha önce estetik amaçlı bir ameliyat deneyimi & 57.8 \\
olma durumu & 182 & 42.2 \\
Olan & 133 & \\
Olmayan & & 63.5 \\
Vücudunun herhangi bir yerini beğenmediği için estetik amaçlı bir ameliyat & 36.5 \\
geçirmeyi isteme durumu & 200 & 2.2 \\
İsteyen & 115 & 4.8 \\
İstemeyen & & 5.7 \\
Estetik amaçlı ameliyat geçirmek istenilen bölge* & 7 & 6.0 \\
Kulak & 15 & 6.3 \\
Kalça & 18 & 8.9 \\
Kaş & 19 & 21.0 \\
Bacak & 20 & 33.7 \\
Karıcı & 28 & 66 \\
Meme & 106 & \\
Burun & &
\end{tabular}

$\mathrm{Bu}$ araştırmada kadınların KCKÖ toplam puan ortalamasinın $50.5 \pm 22.4$ (min:15 maks:105) olduğu saptanmıştır. Kontrol grubunun KCKÖ toplam puan ortalamasının 46.4 \pm 20.8 (min:15 maks:99), deney grubunun ise $54.8 \pm 23.3$ (min:16 maks:105) puan olduğu belirlenmiştir. Deney grubuna alınan kadınların KCKÖ toplam puan ortalamasının kontrol grubuna alınan kadınların puan ortalamasindan istatistiksel olarak anlaml düzeyde yüksek olduğu saptanmıştır (U:9904.50, p:0.002). Deney ve kontrol gruplarının değişkenlere göre estetik cerrahi kabul ölçeği puan ortalamalarının dağılımı tabloda verilmiştir (Tablo 3). Bu çalışmada deney ve kontrol gruplarının KCKÖ toplam puan ortalamasının medeni durum, eğitim seviyesi, aktif olarak sosyal medya kullanma durumu, sosyal medyada estetik cerrahi ameliyatı yapan hekim ya da merkez takip etme durumu, sosyal medyada takip ettiği kişi sayısı, estetik amaçlı herhangi bir ameliyat ya da işlem geçirme durumu, estetik amaçlı bir ameliyat geçiren yakını olma durumu ve estetik amaçlı bir ameliyat geçirmeyi isteme durumundan etkilendiği belirlenmiştir (Tablo $3)$. 
Tablo 3. Deney ve kontrol gruplarının değişkenlere göre kozmetik cerrahi kabul ölçeği puan ortalamalarının dağılımı

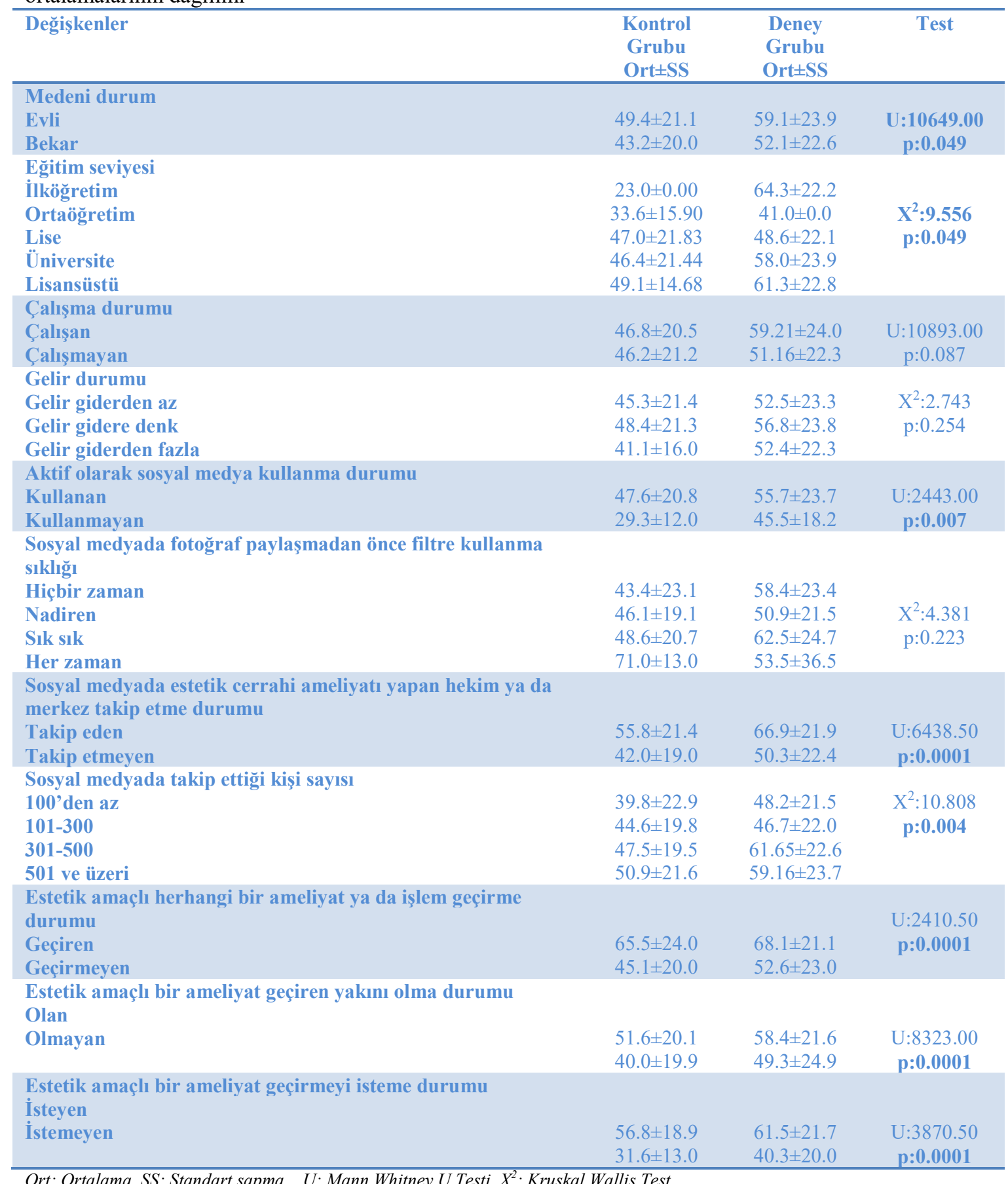

\section{Tartışma ve Sonuç}

Kadınların sosyal medya kullanımının estetik cerrahiye ilişkin tutumlarının incelendiği bu çalışmada en temel bulgularından birinin çalışmamıza katılan kadınlar arasından sosyal medyayı kullanan ve kullanmayan kadınların KCKÖ puan ortalaması arasındaki anlamlı fark olmuştur (U:2443.00, p:0.007). Buna

göre kontrol grubundaki kadınlar arasından sosyal medyayı aktif olarak kullananların KCKÖ puan ortalamalarının sosyal medyayı aktif olarak kullanmayanlarınkine göre yüksek bulunmuştur. Yine sosyal medya görsellerinin gösterildiği deney grubunda sosyal medyayı aktif olarak kullananların KCKÖ puan 
ortalamalarının sosyal medyayı aktif olarak kullanmayanlarınkine göre yüksek bulunmuştur. Arab ve arkadaşları (2019) yaş ortalamas1 $21.15 \pm 2.52$ olan 814 kadınla yaptıkları çalışmalarında kadınların \%48.5'i, estetik cerrahi düşünmek için sosyal medyadan etkilendiği bildirilmiştir. $\mathrm{Bu}$ çalışmanın sonuçları Arab ve arkadaşları tarafından yürütülen çalışmanın sonuçları ile benzerlik göstermektedir (5). De Vries ve arkadaşları (2014) tarafindan yapılan bir çalışmada ergenlerin sosyal paylaşım sitesi kullanımı ile estetik cerrahi geçirme arzusu arasında ilişki olduğu belirtildi (10). Her iki çalışmanın bu çalışmaya göre daha genç popülasyonda yapılmasına karşın sonuçları bu çalışmanın ana bulgusu ile benzerlik göstermektedir. Sarwer ve arkadaşları tarafından yürütülen çalışmaya göre sosyal medya kullanımının artması, estetik cerrahinin faydaları ve bunlara nasıl ulaşılacağ konusunda halkın farkındalı̆̆ının artırmış olabileceğidir (11). Janatolmakan ve arkadaşları tarafından yürütülen bir çalışmada medya, dergi, internet, televizyon, aile ve arkadaşlar gibi sosyal faktörlerin hemşirelerin estetik cerrahi geçirme isteklerini etkilediği belirtilmiştir (12). Shome ve arkadaşları öz çekim (selfie) yapmanın Hintli bireylerin esteik cerrahi geçirme isteğini arttırdığı belirtilmiștir (13). Tüm bu sonuçlara rağmen Brown ve arkadaşları (2007) çalışmalarında sosyal medyanın doyuruculuğunun ve ikna edici özelliğini yitirmesi nedeniyle estetik cerrahi isteğini etkilemediğini bildirmiştir (6).

$\mathrm{Bu}$ çalışmadaki bir diğer önemli bulgu ise sosyal medyada siklıkla gösterilen görsellerin kadınların KCKÖ puanını etkilediği olmuştur. Estetik cerrahi geçirmiş kadın temalı resim setlerinin gösterildiği deney grubuna alınan kadınların KCKÖ toplam puan ortalamasının manzara temalı resim setlerinin gösterildiği kontrol grubuna göre daha yüksek olması istatistiksel olarak ileri düzeyde anlamlı bulunmuştur (U:9904.50 p:0.002). Literatürle de benzerlik gösteren bu sonuç özellikle instagram gibi görsellerin ön planda olduğu sosyal medyanın estetik cerrahi geçirme isteğini etkilediğini düşündürmüştür $(14,15)$.

Sosyal medyada estetik cerrahi ameliyatı yapan hekim ya da merkezi takip etme durumu KCKÖ puan ortalamasının etkileyen bir diğer anlamlı değişken olarak saptanmıştır. Buna göre estetik cerrahi ameliyatı yapan hekim ya da merkez takip eden kontrol ve deney grubundaki kadınların KCKÖ puanları belirgin bir şekilde, takip etmeyen kontrol ve deney grubuna göre istatiksel olarak anlamlı bir şekilde daha yüksek bulunmuştur (U:6438.50, p:0.0001). Arab ve arkadaşlarının (2019) çalışmalarında, sosyal medyadan etkilenenlerin \%66'sının estetik cerrahları sosyal medya platformlarında takip ettiğini ortaya koymuştur (5). Bulgularımız Arab ve arkadaşlarının çalışmasına benzerlik göstermektedir.

Bu çalışmada kadınların sosyal medyada takip ettiği kişi sayısı estetik cerrahi kabulünü etkileyen bir faktör olarak karşımıza çıkmıştır. Takip edilen kişi sayısının sosyal medyayı kullanma ile doğrusal bir ilişkisi olduğunu düşünecek olursak gerek kontrol gerekse deney grubundaki kadınların takip ettiği kişi sayısı arttıkça KCKÖ puan ortalamasının arttığı saptanmıstır. İstatistiksel olarak da anlamlı olan $\left(\mathrm{X}^{2}: 10.808\right.$, p:0.004) bu sonuç sosyal medyayı daha sık kullanan kadınların estetik cerrahiyi daha çok kabul ettiklerini düşündürmüştür (16).

$\mathrm{Bu}$ araştırmada beklenilenin aksine ekonomik düzey ve çalışma durumunun estetik cerrahiyi kabul etme durumunu etkilemediği sonucuna varılmıştır. Fakat Azin ve arkadaşlarının çalışmasında (2014) vücut şekillendirme ameliyatlarını incelediği çalışmada cerrahi isteği etkileyen en önemli engelin ekonomik durum olduğunu saptanmıştır (17).

Estetik cerrahinin kabulü etkiyen sosyodemografik değişkenlerin genellikle medeni durum (U:10649.00, p: 0.049) ve eğitim durumu olduğu ( $\mathrm{X}^{2}: 9.556$, p:0.049); KCKÖ puan ortalamasinin kontrol grubu ile deney grubu arasında istatistiksel olarak anlamlı fark oluşturduğu, deney grubunda ve evli olanların KCKÖ toplam puanının diğer gruplara göre daha yüksek olduğu bulunmuştur. Literatürde estetik cerrahinin cinsel, sosyal ve romantik yaşamla ilişkisinin araştırıldığı bir çalışmada sosyo-demografik özelliklerin (cinsiyet, yaş, medeni durum, romantik bir ilişki, eğitim) 
estetik cerrahi geçirmeyi etkileyen etmenler olduğu ortaya kondu (18).

Yine bu çalışmada estetik amaçlı ameliyat geçiren yakını olma durumunun KCKÖ puanının etkilediği, kontrol grubunda cerrahi geçiren yakını olanların ölçek puan ortalamasının deney grubunda cerrahi geçiren yakını olanların ölçek puan ortalamasından düşük olduğu belirlenmiștir (U:3870.50 p:0.0001) Bu durum Arab ve ark (2019) çalışmasında benzer şekilde bulunmuş olup, estetik cerrahi geçirdikten sonraki olası görüntüsü hakkındaki tahmini estetik cerrahi geçirme isteğini etkilediğini düşündürmüştür (5).

Estetik değişiklik arayışının nedenleri üzerine yapılan araştırmaların çoğu cerrahi estetik deneyimler üzerinde yapılmıştır. Literatürden farklı olarak bu çalışma, sosyal medya kullanımının kadınların estetik cerrahi isteği üzerindeki nedensel etkilerini belirlemede önemli bir adımı oluşturmaktadır. Ayrıca son zamanlarda artan hasta sayısı, farkındalık ve estetik cerrahinin kabulüyle birlikte, kadınları estetik cerrahiyi düşünmeye neyin etki ettiğini belirlemek bu hastalara bakım veren hemşirelere yol göstermesi açısından oldukça önemlidir. Çünkü sosyal medyada görülen birine benzemek için estetik cerrahi geçirmek isteyen bir hastada estetik cerrahi sonuçlarının olumlu olmas1 dolayisiyla hasta memnuniyetinin yüksek olması pek olası değildir (3). Bu doğrultuda estetik cerrahi hastalarının bakım süreçlerinde psikolojik taramalara daha fazla önem verilmesi hastaların hasta ve cerrahi sonuçlarına olumlu katkı sağlayabilir.

Verilerin kesitsel ve tanımlayıcı tipte olması çalışmanın sınırlılığını oluşturmaktadır. Bunun yanında örneklem grubuna alınan kadınların bir kısmının estetik cerrahi deneyiminin olmaması çalışmanın bir diğer sinırlılığıdır. $\mathrm{Bu}$ doğrultuda çalışmanın sinırlılıkları göz önüne alındığında niteliksel, boylamsal gibi farklı çalışma yöntemlerinin kullanıldığı çalışmalar yapılması gerektiği söylenebilir. Ayrıca estetik cerrahi geçirmiş olan katılımcıların dahil edildiği çalışmalar ile sosyal medyanın estetik cerrahiye karar vermede kararlarını ne ölçüde etkili olduğunu değerlendirmek benzer şekilde değerli olabilir.

$\mathrm{Bu}$ çalışma sonucunda estetik cerrahi geçiren kadınların resimlerinin sosyal medya aracılığıyla takip edilmesinin kadınların beden imaj1 üzerinde olumsuz etkisi olduğu dolayısıyla estetik cerrahi geçirmeye yönelimi arttırdığı belirlenmiștir. $\mathrm{Bu}$ doğrultuda toplumda medya okuryazarlığ beden algısının geliştirilmesine yönelik eğitimlerin uygulanması önerilmektedir. Ayrıca sosyal medya dişındaki etkilerin de olduğunu ortaya çıkaran çalışmamız bu konunun derinlemesine incelendiği çalışmalara ihtiyaç olduğunu da göstermiştir.

\section{KAYNAKLAR}

1. Aldosari BF, Alkarzae M, Almuhaya R, Aldhahri $\mathrm{R}$, Alrashid H. Effect of media on facial plastic surgery in Saudi Arabia. Cureus. 2019;11:1-10.

2. von Soest T, Kvalem IL, Roald HE, Skolleborg KC. The effects of cosmetic surgery on body image, self-esteem, and psychological problems. $J$ Plast Reconstr Aesthetic Surg. 2009;62:1238-44.

3. Walker CE, Krumhuber EG, Dayan S, Furnham A. Effects of social media use on desire for cosmetic surgery among young women. Curr Psychol. 2019;

4. ISAPS. ISAPS International survey on aesthetic / cosmetic procedures performed in 2019 [Internet]. [cited 2020 Dec 31]. Available from: https://www.isaps.org/wpcontent/uploads/2020/12/Global-Survey-2019.pdf

5. Arab K, Barasain O, Altaweel A, Alkhayyal J,

Alshiha L, Barasain R, et al. Influence of social media on the decision to undergo a cosmetic procedure. Plast Reconstr Surg - Glob Open. 2019;7:1-7.

6. Brown A, Furnham A, Glanville L, Swami V. Factors that affect the likelihood of undergoing cosmetic surgery. Aesthetic Surg J. 2007;27:5018.

7. Mattei V, Bagliacca E, Ambrosi A, Lanfranchi L, Preis F, Sarno L. The impact of cosmetic plastic surgery on body image and psychological wellbeing: a preliminary study. Int $J$ Psychol Behav Anal. 2015;1: 103.

8. Furnham A, Levitas J. Factors that motivate people to undergo cosmetic surgery. Can J Plast Surg. 2012;20:47-50.

9. Karaca S, Karakoc A, Onan N, Kadıoğlu H. 
Validity and reliability of the Turkish version of the acceptance of cosmetic surgery scale (ACSS). J Psychiatr Nurs. 2017;8:17-22.

10. de Vries DA, Peter J, Nikken P, de Graaf H. The effect of social network site use on appearance investment and desire for cosmetic surgery among adolescent boys and girls. Sex Roles. 2014;71:283-95.

11. Sarwer D, Wadden $T$, Whitaker L. An investigation of changes in body image following cosmetic surgery. Plast Reconstr Surg. 2002;109:363-9.

12. Janatolmakan $\mathrm{M}$, Soroush A, Andayeshgar B, Vahdat A, Khatony A. Factors affecting the desire to undergo cosmetic procedures among the nurses of Kermanshah, Iran: A Cross-Sectional Study. Plast Surg Nurs. 2020;40:205-10.

13. Shome D, Vadera S, Male SR, Kapoor R. Does taking selfies lead to increased desire to undergo cosmetic surgery. $J$ Cosmet Dermatol. 2020;19:2025-32.

14. Rohrich RJ, Savetsky IL, Savetsky EB, Avashia YJ. Why social media is transforming plastic surgery. Indian J Plast Surg. 2020;53:4-5.

15. Eggerstedt M, Rhee J, Urban MJ, Mangahas A, Smith RM, Revenaugh PC. Beauty is in the eye of the follower: Facial aesthetics in the age of social media. Am J Otolaryngol - Head Neck Med Surg 2020;41:102643.

16. Longobardi C, Settanni M, Fabris MA, Marengo D. Follow or be followed: Exploring the links between Instagram popularity, social media addiction, cyber victimization, and subjective happiness in Italian adolescents. Child Youth Serv Rev [Internet]. 2020;113(December 2019):104955.

17. Azin A, Zhou C, Jackson T, Cassin S, Sockalingam S, Hawa R. Body contouring surgery after bariatric surgery: A study of cost as a barrier and impact on psychological well-being. Plast Reconstr Surg. 2014;133:776-82.

18. Asimakopoulou E, Zavrides HAT. Plastic surgery on body image, body satisfaction and self-esteem. Acta Chir Plast. 2020;61:3-9. 